\title{
Avaliação micológica de rações comerciais para cães e gatos e potencial micotoxinogênico de espécies selecionadas*
}

\author{
MARINA VENTURINI COPETTI
}

\author{
Laerte Ferreiro (Orientador - UFRGS)
}

Janio Morais Santurio (Co-orientador - UFSM)

Banca: Isa Beatriz Noll (UFRGS), Jair Putzke (UNISC), Sydney Hartz Alves (UFSM)

A eficácia dos meios ágar batata acidificado, ágar dicloram rosa de bengala e cloranfenicol e ágar dicloram glicerol $18 \%$ foi comparada para isolamento e quantificação de fungos a partir da análise de 54 amostras de rações comerciais secas para cães e gatos (34 para cães e 20 para gatos), produzidas por 9 empresas. A atividade de água das amostras foi quantificada, apresentando valores entre 0,45 e 0,82 . Em $74 \%$ das amostras foi detectada a presença fúngica, onde, além de fungos com micélio estéril e leveduras, 23 gêneros de fungos foram identificados. As 40 amostras positivas apresentaram níveis de contaminação, com contagens variando entre $10^{1}$ e $10^{3} \mathrm{UFC} / g$. Não se verificou correlação entre atividade de água e contaminação fúngica e não se observou diferença significativa entre o número de colônias isoladas e os diferentes meios de cultivo utilizados. Apesar disto, o DG18 foi o meio que apresentou melhores resultados tanto na quantidade quanto na variedade de fungos isolados. Comparandose os resultados obtidos com diferentes meios observa-se que os microrganismos isolados dependem dos meios de cultivo empregados. O gênero Aspergillus e a espécie Aspergillus niger foram os mais freqüentemente isolados. Isolados pertencentes a espécies potencialmente produtoras de aflatoxinas e ocratoxina A foram avaliados através do método de ágar plug-TLC. Vinte por cento dos A. flavus isolados produziram aflatoxina $\mathrm{B} 1$, todos os isolados de A. ochraceus produziram ocratoxina $\mathrm{A}$ e nenhum isolado de A. niger foi detectado como produtor de ocratoxina através do método de screening utilizado. A avaliação fúngica realizada com o emprego de 3 meios de cultura tornou claro que a detecção de fungos é dependente do meio de cultura utilizado. A Aw do alimento e do meio também devem ser consideradas para que as análises microbiológicas possam detectar ou valorar a micobiota que, efetivamente, está contaminando o alimento.

Descritores: Micobiota, ração, meios de cultivo, fungos em alimentos, micotoxinas, Aspergillus. 


\title{
Micological evaluation of commercial pet food and mycotoxigenic potential of selected species ${ }^{* *}$
}

\author{
MARINA VENTURINI COPETTI
}

\author{
Laerte Ferreiro (Adviser - UFRGS)
}

Janio Morais Santurio (Co-Adviser - UFSM)

Commitee: Isa Beatriz Noll (UFRGS), Jair Putzke (UNISC), Sydney Hartz Alves (UFSM)

The efficacy of potato dextrose agar acidified, dichloran rose bengala agar and dichloran glycerol $18 \%$ agar media were compared for isolation and enumeration of fungi present in 54 commercial packages of Brazilian dry, cereal based, pet foods (20 for cat and 34 for dog consumption) manufactured by 9 companies. Water activity of samples ranged between 0.45 and 0.82. Fungal presence was detected in $74 \%$ of samples. The survey showed presence of 23 genera and fungi identified as Mycelia sterilia and yeasts. No fungal species was recovered in 14 samples ( 8 for dog and 6 for cat). The forty positive samples showed low levels of contamination, ranged from $10^{1}$ to $10^{3} \mathrm{CFU} / \mathrm{g}$. There was no correlation verified between water activity and level of fungal contamination. There was no statistical difference between the number of fungi isolated and media employed, even though DG18\% agar showed better results in relationship to quantity and variety of isolated moulds. Comparison of results obtained through the three employed media, allows to observe that microorganisms recovered varies according to the employed media. The genus Aspergillus and particularly Aspergillus niger were the most frequent moulds recovered. Isolates belonging to potentially aflatoxins and ocrhatoxi A-producing species were evaluated using the agar plug-TLC screening method. Twenty percent of A. flavus were aflatoxin B1-producers; all isolates of A. ochraceus were ochratoxin A producers and all samples of $A$. niger being negatives for this toxin production. Fungal evaluation proceeded with 3 culture media showed that fungal detection is dependent of media chosen to make the analysis and corroborate importance to considerate the Aw of food and media to access the mycobiota present in the food.

Key words: mycobiota, pet food, food borne fungi, mycotoxin, Aspergillus. 